\title{
Amphetamine-evoked c-fos mRNA expression in the caudate-putamen: the effects of DA and NMDA receptor antagonists vary as a function of neuronal phenotype and environmental context
}

\author{
Susan M. Ferguson, ${ }^{*}$ Camille S. Norton, $\uparrow$ Stanley J. Watson, ${ }^{*} \uparrow$ Huda Akil ${ }^{*} \uparrow$ \\ and Terry E. Robinson* $\%$ \\ *Neuroscience Program, †Mental Health Research Institute and $\ddagger$ Department of Psychology, University of Michigan, Ann Arbor, \\ Michigan, USA
}

\begin{abstract}
Dopamine (DA) and glutamate neurotransmission is thought to be critical for psychostimulant drugs to induce immediate early genes (IEGs) in the caudate-putamen (CPu). We report here, however, that the ability of DA and glutamate NMDA receptor antagonists to attenuate amphetamine-evoked c-fos mRNA expression in the $\mathrm{CPu}$ depends on environmental context. When given in the home cage, amphetamine induced c-fos mRNA expression predominately in preprodynorphin and preprotachykinin mRNA-containing neurons (Dyn-SP+ cells) in the CPu. In this condition, all of the D1R, D2R and NMDAR antagonists tested dose-dependently decreased c-fos expression in Dyn-SP+ cells. When given in a novel environment, amphetamine induced c-fos mRNA in both Dyn$\mathrm{SP}+$ and preproenkephalin mRNA-containing neurons (Enk+ cells). In this condition, D1R and non-selective NMDAR
\end{abstract}

antagonists dose-dependently decreased c-fos expression in Dyn-SP+ cells, but neither D2R nor NR2B-selective NMDAR antagonists had no effect. Furthermore, amphetamine-evoked c-fos expression in Enk+ cells was most sensitive to DAR and NMDAR antagonism; the lowest dose of every antagonist tested significantly decreased c-fos expression only in these cells. Finally, novelty-stress also induced c-fos expression in both Dyn-SP+ and Enk+ cells, and this was relatively resistant to all but D1R antagonists. We suggest that the mechanism(s) by which amphetamine evokes c-fos expression in the $\mathrm{CPu}$ varies depending on the stimulus (amphetamine vs. stress), the striatal cell population engaged (Dyn-SP+ vs. Enk+ cells), and environmental context (home vs. novel cage).

Keywords: dopamine, glutamate, immediate early genes, in situ hybridization, striatum, rat.

J. Neurochem. (2003) 86, 33-44.
Psychostimulant drugs are reported to induce immediate early genes (IEGs) only in a specific subclass of projection neurons in the caudate-putamen $(\mathrm{CPu})$ - striatonigral GABAergic neurons that co-express mRNA for dopamine (DA) D1Rs, preprodynorphin and preprotachykinin (Dyn-SP+ cells) (Berretta et al. 1992; Cenci et al. 1992; Berretta et al. 1993; Johansson et al. 1994; Ruskin and Marshall 1994; see Harlan and Garcia 1998 for review). The ability of psychostimulant drugs to induce IEGs in Dyn-SP+ cells involves both DA and glutamate receptors, because both DA (Graybiel et al. 1990; Young et al. 1991; Ruskin and Marshall 1994; LaHoste et al. 2000) and glutamate receptor antagonists (Dragunow et al. 1991; Snyder-Keller 1991; Wang et al. 1994; Konradi et al. 1996) markedly reduce amphetamine- and cocaine-evoked IEG expression in the $\mathrm{CPu}$.
These studies have provided important information about the neural circuits engaged by potentially addictive drugs, the neurotransmitter systems involved, and about the initial steps in the cascade of molecular changes that may contribute to

Received February 18, 2003; revised manuscript received March 10, 2003; accepted March 11, 2003.

Address correspondence and reprint requests to Terry E. Robinson, Department of Psychology (Biopsychology), The University of Michigan, 525 East University Ave., Ann Arbor, MI 48109-1109, USA. E-mail: ter@umich.edu

Abbreviations used: $\mathrm{CPu}$, caudate-putamen; DA, dopamine; dISH, dual in situ hybridization histochemistry; EPSPs, excitatory post-synaptic potentials; ERK1/2/MAPK, extracellular signal-regulated kinase/ mitogen-activated protein kinase; 5-HT, serotonin; IEGs, immediate early genes; i.p., intraperitoneal; nNOS, neuronal nitric oxide synthase. 
drug experience-dependent plasticity (Nestler et al. 1993; Hyman and Malenka 2001).

However, the selectivity of psychostimulant drug effects on Dyn-SP+ cells may be more apparent than real, because it is largely dependent on the context in which these drugs are administered (Badiani et al. 1999). When given in the home cage, amphetamine and cocaine induce c-fos expression primarily in Dyn-SP+ cells, but when given in a novel environment these drugs also induce c-fos expression in a second subclass of striatal projection neurons - striatopallidal GABAergic neurons that co-express mRNA for DA D2Rs and preproenkephalin (Enk+ cells) (Jaber et al. 1995; Badiani et al. 1999; Uslaner et al. 2001b, 2003). There is no information regarding the neurotransmitter systems responsible for psychostimulant-induced IEG expression in Enk + cells, because in previous studies drugs were only given in the home cage. This is an important issue because drugs are taken under many different conditions, and 'set and setting' has an enormous effect on both the acute behavioral and subjective effects of drugs, as well as on their ability to induce forms of drug experience-dependent plasticity (Falk and Feingold 1987; Robinson et al. 1998).

To begin to address which neurotransmitter systems mediate psychostimulant-evoked IEG expression in different striatal cell populations, we used dual in situ hybridization histochemistry to study the effects of DA and glutamate receptor antagonists on c-fos mRNA expression in both Dyn$\mathrm{SP}+$ and Enk + cells in the dorsomedial $\mathrm{CPu}$ under three different conditions: (i) following exposure to a novel environment ('novelty stress'); (ii) following amphetamine administration in the home cage; and (iii) following amphetamine administration in a novel test cage. We report that the effects of these antagonists on c-fos mRNA expression in the $\mathrm{CPu}$ vary markedly as a function of neuronal phenotype and environmental context.

\section{Materials and methods}

\section{Subjects}

Male Sprague-Dawley rats (Harlan Sprague Dawley, Indianapolis, IN, USA), weighing 200-225 g upon arrival, were initially housed singly in square, plastic, clear cages containing either pine shavings or shredded paper bedding, and were allowed to acclimate to the animal colony room for 1 week prior to any experimental manipulation. The rooms were temperature- and humidity-controlled and maintained on a $14: 10 \mathrm{~h}$ light : dark cycle, with food and water available ad libitum. All experimental procedures were approved by the University of Michigan Committee on the Use and Care of Animals.

\section{Groups and test procedures}

Rats were randomly assigned to one of two groups. In all experiments, one group of animals (HOME) was transferred from the main animal colony to another room and placed individually into orange, circular buckets ( $25 \mathrm{~cm}$ diameter at the base) with ground corncob bedding on the floor. They remained in these cages for the duration of the experiment. Animals in the other group (NOVEL) remained in the main animal colony room. On the day of testing, which was 7 days after the HOME animals were housed in orange buckets, all animals in both groups received an intraperitoneal (i.p.) injection (in their home cage) of either saline, SCH-23390 (in one experiment 0.005 or 0.01 , and another $0.05,0.1$ or $0.5 \mathrm{mg} / \mathrm{kg}$ ), SCH-39166 $(0.01,0.03,0.1$, or $0.3 \mathrm{mg} / \mathrm{kg}), \mathrm{L}-741,262(2.5,5$ or $10 \mathrm{mg} / \mathrm{kg})( \pm)$-3-(2-carboxypiperazin-4-yl)-propyl-1-phosphonic acid (CPP; 1 or $10 \mathrm{mg} / \mathrm{kg}$ ), ifenprodil (1 or $10 \mathrm{mg} / \mathrm{kg}$ ) or MK-801 $(0.5$ or $1 \mathrm{mg} / \mathrm{kg}$ ). Thirty minutes later, animals in the HOME groups received an injection of saline or $2 \mathrm{mg} / \mathrm{kg}$ of $d$-amphetamine sulfate in their home cage (i.e. the orange circular buckets) and animals in the NOVEL groups were transported to a testing room where they received an injection of saline or amphetamine and were immediately placed into orange circular buckets physically identical to those in which animals in the HOME groups lived (but distinct from their own home cages). A third untreated group was used as a control group to assess basal levels of c-fos mRNA expression. These animals remained in the animal colony room during testing and received no injections. Fifty minutes after the second injection, all animals were decapitated in the absence of further drug treatments, their brains removed, frozen in isopentane and stored at $-70^{\circ} \mathrm{C}$. Each antagonist was tested in separate experiments, with their own control groups, except animals given CPP and the lower doses of $\mathrm{SCH}-23390(0.005-0.05 \mathrm{mg} / \mathrm{kg})$, which were tested in the same experiment. The tissue from each experiment was processed for dual in situ hybridization histochemistry (dISH) at the same time.

\section{Dual in situ hybridization methods}

The brains were sectioned using a cryostat and $16-\mu \mathrm{m}$ coronal sections were thaw-mounted onto polylysine-coated slides and stored at $-70^{\circ} \mathrm{C}$ until processed for dISH. The method was a modification of that described by Curran and Watson (1995). Slides containing four tissue sections were processed using a $\left[{ }^{35} \mathrm{~S}\right] \mathrm{UTP}$ and -CTP labeled riboprobe complementary to c-fos (680-mer, courtesy of Dr T. Curran, St. Jude Children's Research Hospital, Memphis, TN, USA) and a digoxigenin-UTP labeled riboprobe complementary to preprodynorphin, preprotachykinin (substance P) or preproenkephalin (733-mer, 567-mer and 693-mer, respectively; courtesy of Dr J. Douglass, Amgen, Thousand Oaks, CA, USA). The radioactive riboprobe was generated by incubating linearized c-fos DNA $(1 \mu \mathrm{g})$ at $37^{\circ} \mathrm{C}$ for $1.5 \mathrm{~h}$ in $1 \times$ transcription buffer, $80 \mu \mathrm{Ci}$ of $\left[\alpha-{ }^{35}\right.$ S]UTP $(100 \mathrm{Ci} / \mathrm{mm} ; 20 \mathrm{mCi} / \mathrm{mL}$; Amersham, Arlington Heights, IL, USA $), 120 \mu \mathrm{Ci}$ of $\left[\alpha-{ }^{35} \mathrm{~S}\right] \mathrm{CTP}(800 \mathrm{Ci} / \mathrm{mm} ; 40 \mathrm{mCi} / \mathrm{mL}$; Amersham), $400 \mu \mathrm{M}$ GTP, $400 \mu \mathrm{M}$ ATP, 8 mм dithiothreitol (DTT), $20 \mathrm{U}$ RNase Inhibitor and $6 \mathrm{U}$ of T7 RNA polymerase. The nonradioactive riboprobes were generated by incubating linearized preprodynorphin, preprotachykinin or preproenkephalin DNA $(1 \mu \mathrm{g})$ at $37^{\circ} \mathrm{C}$ for $1.5 \mathrm{~h}$ in $1 \times$ transcription buffer, $320 \mu \mathrm{M}$ digoxigenin-UTP (dig-UTP; Boehringer, Mannheim, Germany), $80 \mu \mathrm{M}$ UTP, $400 \mu \mathrm{M}$ GTP, $400 \mu \mathrm{M}$ ATP, $400 \mu \mathrm{M} \mathrm{CTP,} 10$ mм DTT, $40 \mathrm{U}$ RNase inhibitor and $200 \mathrm{U}$ of T7 RNA polymerase. The resulting probes were incubated at $22^{\circ} \mathrm{C}$ with $125 \mathrm{U}$ of Rnase-free DNase for $15 \mathrm{~min}$ and then separated from free nucleotides on Sephadex G50-50 columns.

Prior to hybridization, tissue sections were fixed in $4 \%$ phosphate-buffered paraformaldehyde for $1 \mathrm{~h}$ at room temperature, 
rinsed three times in $2 \times \mathrm{SSC}$, placed into a solution of $0.1 \mathrm{M}$ triethanolamine $/ 0.25 \%$ acetic acid for $10 \mathrm{~min}$, rinsed in water and dehydrated in a series of graded alcohols (50-100\%). The ${ }^{35} \mathrm{~S}$-labeled and dig-UTP labeled probes were diluted in hybridization buffer $(50 \%$ formamide, $10 \%$ dextran sulfate, $3 \times \mathrm{SSC}, 50 \mathrm{~mm}$ sodium phosphate, $\mathrm{pH} 7.4,1 \times$ Denhardt's solution and $10 \mathrm{mg} / \mathrm{mL}$ yeast tRNA) to give an approximate concentration of 2.5-3.0 $\times 10^{6}$ d.p.m. $/ 70 \mu \mathrm{L}$. The appropriate concentration of the non-radioactive probe was determined based on pilot studies. Slides were coverslipped with diluted probe $(70 \mu \mathrm{L})$ and placed in hybridization trays lined with filter paper dampened with $50 \%$ formamide $/ 50 \%$ water. The trays were sealed and incubated at $55^{\circ} \mathrm{C}$ for $16 \mathrm{~h}$. Coverslips were floated off in $2 \times \mathrm{SSC}$ and the slides were rinsed three times in $2 \times$ SSC. The slides were then incubated in RNase A $(200 \mu \mathrm{g} / \mathrm{mL})$ at $37^{\circ} \mathrm{C}$ for $1 \mathrm{~h}$, rinsed in $2 \times, 1 \times, 0.5 \times$, incubated in $0.1 \times \mathrm{SCC}$ at $65^{\circ} \mathrm{C}$ for $1 \mathrm{~h}$ and then cooled to room temperature. The slides were rinsed in $0.1 \mathrm{M}$ sodium phosphate buffer ( $\mathrm{pH} 7.4)$, incubated with shaking for $1 \mathrm{~h}$ at room temperature in a blocking solution $(0.25 \%$ carageenan, $0.5 \%$ Triton- $\mathrm{X}, 0.1 \mathrm{M}$ sodium phosphate buffer, and then incubated with shaking overnight at room temperature with an antibody against digoxigenin, conjugated to alkaline phosphatase (sheep antidig AP, Fab fragments; Boehringer) that was diluted $1: 20000$ in a blocking solution. Slides were then incubated at room temperature with shaking for two times $(1 \mathrm{~h} \mathrm{each})$ in $0.1 \mathrm{M}$ sodium phosphate buffer, two times (30 min each) in Tris-buffered saline and rinsed in alkaline substrate buffer (ASB) $100 \mathrm{~mm}$ Tris base, $50 \mathrm{~mm} \mathrm{NaCl}, 50 \mathrm{~mm} \mathrm{MgCl}_{2}, \mathrm{pH}$ 9.5. The color reaction was carried out in the dark at room temperature in ASB containing 5\% polyvinyl alcohol (Sigma, St Louis, MO, USA), 0.025\% levamisole (Sigma) and 2\% NBT/BCIP (Boehringer). After $\sim 4 \mathrm{~h}$ for preproenkephalin and $\sim 24 \mathrm{~h}$ for preprodynorphin and preprotachykinin, the color reaction was stopped by washing the slides extensively in water, incubating in $0.1 \mathrm{~m}$ glycine, $0.2 \%$ Triton-X $100, \mathrm{pH} 2.2$ for $10 \mathrm{~min}$ at room temperature and rinsing in water. Slides were then fixed in $2.5 \%$ glutaraldehyde for $2 \mathrm{~h}$, rinsed in water and air-dried.

Slides were exposed to X-ray film (Kodak Biomax MR, Rochester, NY, USA) and then dipped in emulsion (Ilford KD-5, Polysciences) and stored in light-tight boxes at $4^{\circ} \mathrm{C}$ for $5-6$ days. Slides were developed (Kodak D-19) for $2 \mathrm{~min}$ at $17^{\circ} \mathrm{C}$, rinsed in water and fixed (Kodak Rapid Fix) for $3 \mathrm{~min}$ at $17^{\circ} \mathrm{C}$. Slides were then washed extensively in water, dehydrated in a series of graded alcohols (50-100\%), washed extensively in xylene and coverslipped with Permount mounting medium.

Control experiments using sense probes or tissue pre-treated with Rnase A ( $200 \mu \mathrm{g} / \mathrm{mL}$ at $37^{\circ} \mathrm{C}$ for $\left.1 \mathrm{~h}\right)$ were performed to ensure probe specificity and no binding was observed with either control. In addition, co-localization experiments were conducted with preprodynorphin mRNA and preprotachykinin mRNA, preprodynorphin mRNA and preproenkephalin mRNA, as well as preprotachykinin mRNA and preproenkephalin mRNA. The preprodynorphin and preprotachykinin probes co-localized, whereas the preproenkephalin probe did not co-localize with either the preprodynorphin probe or the preprotachykinin probe.

\section{Quantification of c-fos mRNA and data analysis}

Initial quantification of c-fos mRNA expression was conducted on autoradiographs of rostral ( $0.0 \mathrm{~mm}$ to bregma) and caudal sections

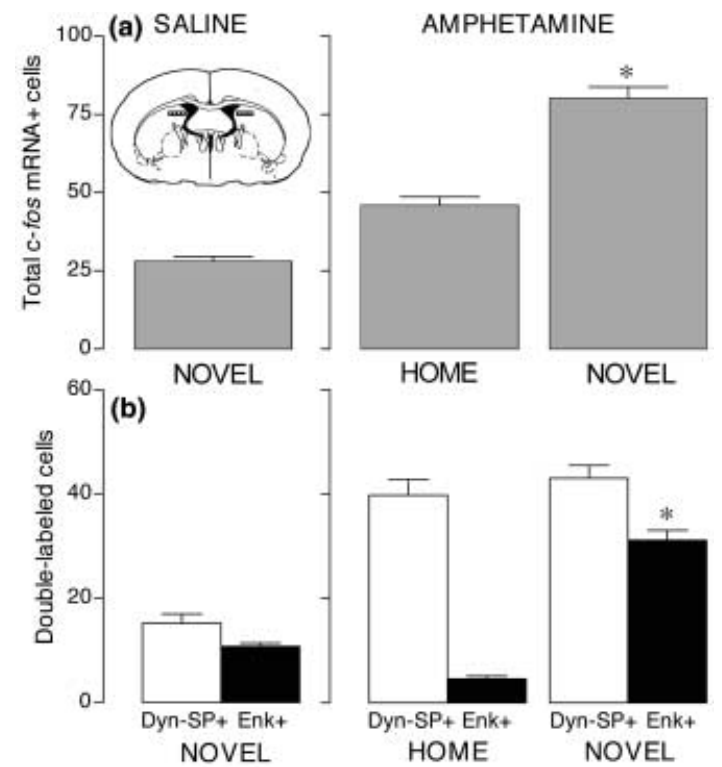

Fig. 1 Expression of c-fos mRNA in the dorso-caudal CPu after exposure to a novel environment, amphetamine or both. The illustration in the upper left panel contains boxes that depict the area of the dorsal $\mathrm{CPu}$ that was quantified (total area $=0.5 \mathrm{~mm}^{2}$ ). Note that to simplify data presentation the mean value of the control group has been subtracted, and therefore, in all graphs basal levels of expression are indicated by a value of zero, and values above zero represent an increase in the number of c-fos+ cells, relative to baseline. (a) The mean ( \pm SEM) number of c-fos+ cells as a function of treatment condition. For all treatment conditions, there was a significant increase in the number of $c$-fos+ cells over baseline (one-sample $t$-tests; novelty stress group, $t=17.42, p<0.0001$; home/amphetamine group, $t=16.79, p<0.0001$; novel/amphetamine group, $t=21.74$, $p<0.0001)$. The number of $c$-fos+ cells was significantly higher in the novel/amphetamine group than in any other group (one-way ANOVA followed by Bonferroni's-tests; $F_{2,72}=86.30, p<0.0001$ ). (b) The mean $( \pm \mathrm{SEM})$ number of c-fos+ cells that were also Dyn-SP+ (white bars) or Enk+ (black bars). For all treatment conditions, there was a significant increase in the number of both c-fos/Dyn-SP+ cells and $c$-fos/Enk+ cells over baseline (all $p<0.0001$ ). For all conditions, there was also a significant effect of cell type; that is, there were more c-fos/ Dyn-SP+ cells than c-fos/Enk + cells $(t=2.6-11.8, p<0.01)$. However, the increase in the total number of $c$-fos+ cells seen in animals given amphetamine in the novel environment was due to an increase in the number of $c$-fos/Enk+ cells $(p<0.001)$, not $c-f o s / D y n-S P+$ cells. ${ }^{*}$, differs from the home/amphetamine group $(p<0.001$, Bonferroni test).

(0.8 $\mathrm{mm}$ posterior to bregma) (Paxinos and Watson 1998) as described previously (Badiani et al. 1998). A similar pattern of c-fos mRNA expression for control groups (i.e. groups not receiving antagonist pre-treatment) and a similar effect of antagonist pretreatment was found across both levels and in multiple subregions (dorsomedial, dorsolateral and ventral) within each level of the $\mathrm{CPu}$. The dorsomedial portion of sections $0.8 \mathrm{~mm}$ posterior to bregma (see Fig. 1) was selected for further analysis because the magnitude of c-fos mRNA expression was greatest at this level of the $\mathrm{CPu}$ in the present study and we previously found the largest effect of 
environmental context on amphetamine-evoked c-fos mRNA expression at this level of the CPu (Badiani et al. 1998; Uslaner et al. 2001b). Quantification was carried out at $40 \times$ magnification using a Leica microscope (Letiz DMR, Wetzler, Germany) on sections from three to seven animals/group. In the dorso-caudal $\mathrm{CPu}$, the total number of single- and double-labeled cells was counted in four $250-\mu \mathrm{m}^{2}$ grids of each hemisphere (for a total of eight grids; see Fig. 1 inset). ${ }^{35}$ S-labeled cells (containing c-fos mRNA) appeared as silver grains under darkfield conditions and dig-labeled cells (containing preprodynorphin, preprotachykinin or preproenkephalin mRNA) appeared as purple precipitate under brightfield conditions. Sections were quantified by an experimenter blind to the experimental conditions. Only ${ }^{35} \mathrm{~S}$-labeled cells that contained dense clusters of silver grains (i.e. at least 10 silver grains/ cell) and dig-labeled cells that were uniformly darkly stained (i.e. at least 10 times above background staining) were considered to be positively labeled cells.

\section{Drugs}

The DA D1R antagonists $R(+)-\mathrm{SCH}-23390$ (Sigma) and SCH39166 (generously donated by Schering-Plough Research Institute, Kenilworth, NJ, USA), the competitive NMDAR antagonist CPP (Sigma), the non-competitive NMDAR antagonist (+)-MK-801 (Sigma) and $d$-amphetamine sulfate (Sigma) were dissolved in $0.9 \%$ saline and injected in a volume of $1 \mathrm{~mL} / \mathrm{kg}$. The DA D2R antagonist L-741,262 (Tocris Cookson, Ballwin, MO, USA) was dissolved in a small amount of glacial acetic acid, diluted in sterile water, the $\mathrm{pH}$ adjusted to 4.5 with sodium hydroxide and injected in a volume of $1.56,3.13$, or $6.25 \mathrm{~mL} / \mathrm{kg}$. The NR2B subunit-selective NMDAR antagonist ifenprodil (Sigma) was dissolved in sterile water and injected in a volume of 1 or $8 \mathrm{~mL} / \mathrm{kg}$. All drugs were administered by i.p. injection. SCH-23390 and MK-801 were chosen because previous studies on psychostimulant-evoked IEG expression used these drugs, allowing us to compare our results with the existing literature. SCH-39166 was chosen because it has very high affinity for D1Rs and very low affinity for serotonin (5-HT) or D2Rs (Duffy et al. 2000). L-741,262 was chosen because it is highly selective for D2Rs over D3 and D4 receptors and by itself has only moderate effects on c-fos expression (LaHoste et al. 2000). CPP was chosen because it circumvents some of the problems associated with the complex pharmacological profile of the non-competitive NMDAR antagonist, MK-801. Ifenprodil was chosen because it is selective for NR2B subunit-containing NMDARs, whereas the other NMDAR antagonists tested are non-selective. The dose ranges and injection times for each antagonist were based on effective doses reported in the existing literature, and on pilot studies. The dose of amphetamine was chosen because it has been shown to induce greater c-fos mRNA expression in the $\mathrm{CPu}$ in animals given amphetamine in a novel environment than in animals given amphetamine at home (Badiani et al. 1998). All drug weights refer to the weight of the salts.

\section{Statistical analysis}

As expected from previous studies, the level of c-fos mRNA expression in the untreated group and the group that received saline injections at home was very low, and these groups did not differ. Therefore, these two groups were pooled. In addition, in all experiments except the one with L-741,262, the antagonist pre-treatment (without amphetamine) did not effect basal levels of c-fos mRNA expression, so these groups were also pooled with the untreated and home/saline groups. This produced a single control group that provided an index of basal c-fos mRNA expression. In the case of the L-741,262 experiment there were two control groups. One control group contained untreated and home/saline animals that did not receive L-741,262 pre-treatment (i.e. they received saline pre-treatment). The mean value for this group was subtracted from each animal not receiving L-741,262 pre-treatment in the other conditions. The second control group contained home/saline animals that received L-741,262 pre-treatment (i.e. they received 2.5, 5 or $10 \mathrm{mg} / \mathrm{kg} \mathrm{L}-741,262$ ). The mean value for this group was subtracted from each animal receiving L-741,262 pre-treatment in the other conditions. To simplify data presentation, the mean value for the control group was subtracted from each animal, and thus, if the mean for any group differs significantly from zero (tested using planned one-sample $t$-tests) this indicates a significant change in c-fos mRNA expression, relative to baseline. Group differences in the total number of c-fos + cells, the number of double-labeled c-fos/ Dyn-SP+ cells or the number of double-labeled c-fos/Enk + cells were tested using one-way analyses of variances (ANOVA) followed by Bonferroni's or Dunnett's posthoc tests. Differences in the number of c-fos/Dyn-SP+ versus c-fos/Enk+ in the same group were analyzed using unpaired $t$-tests. For all comparisons, $\alpha=0.05$.

\section{Results}

\section{Effect of environmental context on c-fos mRNA expression in Dyn-SP and Enk+ cells}

To assess the overall effect of environmental novelty on c-fos mRNA (c-fos) expression in cells containing preprodynorphin or preprotachykinin mRNA (these will be called Dyn$\mathrm{SP}+$ cells) or cells containing preproenkephalin mRNA (these will be called Enk+ cells), data for saline-pre-treated (i.e. not antagonist-pre-treated) animals from four separate dISH experiments were pooled. These data are summarized in Table 1 and Fig. 1. Table 1 shows the total number of cells counted (summed across all animals) and the percent of double-labeled cells (i.e. those positive for c-fos that were also Dyn-SP+ or Enk+, divided by the total number of c- $f \circ s^{+}$ cells), as a function of treatment condition. Figure 1 shows the mean ( \pm SEM) number of c-fos + cells (top) and the mean number of double-labeled cells (bottom), as a function of treatment condition. In Fig. 1, the mean number of c-fos + cells in the control group (untreated plus home-saline group), which was quite small (see Table 1), was subtracted from the value for each animal in the other groups to simplify data presentation and analysis. Thus, on Fig. 1, a value of zero indicates basal levels of c-fos expression and any mean that is statistically greater than zero represents a significant increase in the number of c-fos + cells, relative to this baseline (see figure legends for statistics).

Figure 1 (top) shows that all treatments significantly increased the number of c-fos + cells, although there were 
Table 1 The co-localization of c-fos+ cells and Dyn-SP+ cells (top) or Enk+ cells (bottom) in the dorso-caudal $\mathrm{CPu}$, as a function of treatment condition

\begin{tabular}{lrrlrl}
\hline Group & $n$ & c-fos+ & Dyn/SP+ & Double & Double (\%) \\
\hline Control & 24 & 241 & 3676 & 206 & $87.0 \pm 2.5$ \\
Amph (Home) & 25 & 1397 & 4046 & 1210 & $87.4 \pm 1.2$ \\
Novelty & 22 & 753 & 3402 & 510 & $68.3 \pm 1.7$ \\
Amph + novelty & 25 & 2106 & 3926 & 1292 & $61.4 \pm 1.1$ \\
\hline Group & $n$ & c-fos+ & Enk+ & Double & Double (\%) \\
\hline Control & 23 & 148 & 4410 & 24 & $14.1 \pm 2.7$ \\
Amph (Home) & 25 & 1313 & 4696 & 141 & $11.1 \pm 1.1$ \\
Novelty & 24 & 879 & 4804 & 283 & $33.2 \pm 1.5$ \\
Amph + novelty & 24 & 2179 & 4749 & 772 & $35.4 \pm 0.9$ \\
\hline
\end{tabular}

The columns (left to right) show the group, number of animals/group, the total number of cells counted (summed across all animals) that were only c-fos+, the total number of cells that were only Dyn-SP+ (or Enk+) and the total number of cells that were both c-fost and Dyn-SP+ (or Enk+). For each animal, the percent of all c-fos+ cells that were double-labeled was calculated and the mean $( \pm$ SEM) per cent of double-labeled cells is shown in the last column.

also significant group differences. The number of c-fos + cells was significantly higher in animals given amphetamine in a novel environment than in either animals given saline in the novel environment or animals given amphetamine at home. Figure 1 (bottom) shows the specific cell types (i.e. Dyn-SP+ vs. Enk+) that expressed c-fos and Fig. 2 provides representative examples of c-fos/Enk+ cells in the home and novel conditions. Note that the number of c-fos/Dyn-SP + and c-fos/ Enk + cells accounts for all but a few percent of the total number of c-fos + cells (Table 1), consistent with the fact that these cells represent $90-95 \%$ of all neurons in the $\mathrm{CPu}$. However, the proportion of c-fos + cells that were also Dyn$\mathrm{SP}+$ or Enk + varied significantly as a function of treatment condition. When given at home, amphetamine induced c-fos expression predominately in Dyn-SP+ cells $(87 \%$ of c-fos + cells were Dyn-SP+ and only $11 \%$ were Enk+; Table 1, Fig. 1b). The increase in the total number of c-fos + cells seen when amphetamine was given in a novel environment was due almost entirely to an increase in the number of c-fos/ Enk+ cells (Fig. 1b). Thus, when amphetamine was given in the novel environment, the number of c-fos/Dyn-SP+ cells accounted for only $61 \%$ of the total number of c-fos + cells and the percent of c-fos/Enk + cells rose from $11 \%$ to $35 \%$ of c-fos + cells (Table 1). Mere exposure to the novel environment produced a lower level of c-fos expression compared with animals given amphetamine, but interestingly, the proportion of c-fos/Dyn-SP+ versus c-fos/Enk + cells was similar to that in animals given amphetamine in the novel environment (Table 1 and Fig. 1).
Effect of the DA D1R antagonists, SCH-23390 and SCH-39166, on c-fos mRNA expression in Dyn-SP+ and Enk+ cells

Figure 3 shows the effect of pre-treatment with the DA D1-selective receptor antagonist SCH-23390 on c-fos expression. The top panels show that $\mathrm{SCH}-23390$ dosedependently reduced the total number of c-fos + cells in all groups. The bottom panels show that the effectiveness of SCH-23390 differed depending on treatment condition. In animals given amphetamine at home (panel E) nearly all c-fos ${ }^{+}$cells were also Dyn-SP+, and the highest dose of $\mathrm{SCH}-23390$ reduced the number of c-fos/Dyn-SP+ cells, although this effect did not quite reach statistical significance $(p<0.1$; but see below for the effect of higher doses). Given that there were so few c-fos/Enk+ cells in this condition (panel E), the likelihood of floor effects is high and so the effect of SCH-23390 and the other antagonists on c-fos/Enk+ cells for this condition were not assessed. Amphetamine given in the novel environment (panel F) induced c-fos expression in a comparable number of Dyn$\mathrm{SP}+$ and Enk + cells. SCH-23390 dose-dependently reduced the number of c-fos/Enk+ cells. However, the effect of these doses of SCH-23390 on the number of c-fos/Dyn-SP+ cells was not statistically significant. In animals given saline in the novel environment (panel D), SCH-23990 had no significant effect on c-fos expression in either type of cell. In a second independent experiment, the effect of higher doses of SCH-23390 (0.05, 0.1 and $0.5 \mathrm{mg} / \mathrm{kg})$ was examined using the same experimental design. All three of these higher doses reduced c-fos expression to basal levels in all groups (data not shown).

Figure 4 shows the effect of the highly selective DA D1R antagonist SCH-39166 on c-fos expression. The top panels show that SCH-39166 dose-dependently reduced the total number of c-fos + cells in all conditions, although in animals given saline in the novel environment this effect reached statistical significance only at one dose $(0.1 \mathrm{mg} / \mathrm{kg})$. The bottom panels show that the effectiveness of SCH-39166 differed depending on cell type and drug treatment. In animals given amphetamine at home (panel E) or in the novel environment (panel F) SCH-39166 dose-dependently decreased the number of c-fos/Dyn-SP+ cells. SCH-39166 was especially effective in decreasing the number of c-fos/Enk+ cells in the novel condition. Indeed, the lowest dose tested significantly reduced the number of c-fos/Enk + cells, but not the number of c-fos/Dyn-SP+ cells (panel F). In animals given saline in the novel environment (panel D) there was no statistically significant effect of SCH-39166 on c-fos expression in either type of cell.

\section{Effect of the DA D2R antagonist L-741,262 on c-fos mRNA expression in Dyn-SP+ and Enk+ cells}

Figure 5 shows the effect of pre-treatment with the DA D2R antagonist L-741,262 on c-fos expression. The figure inset 

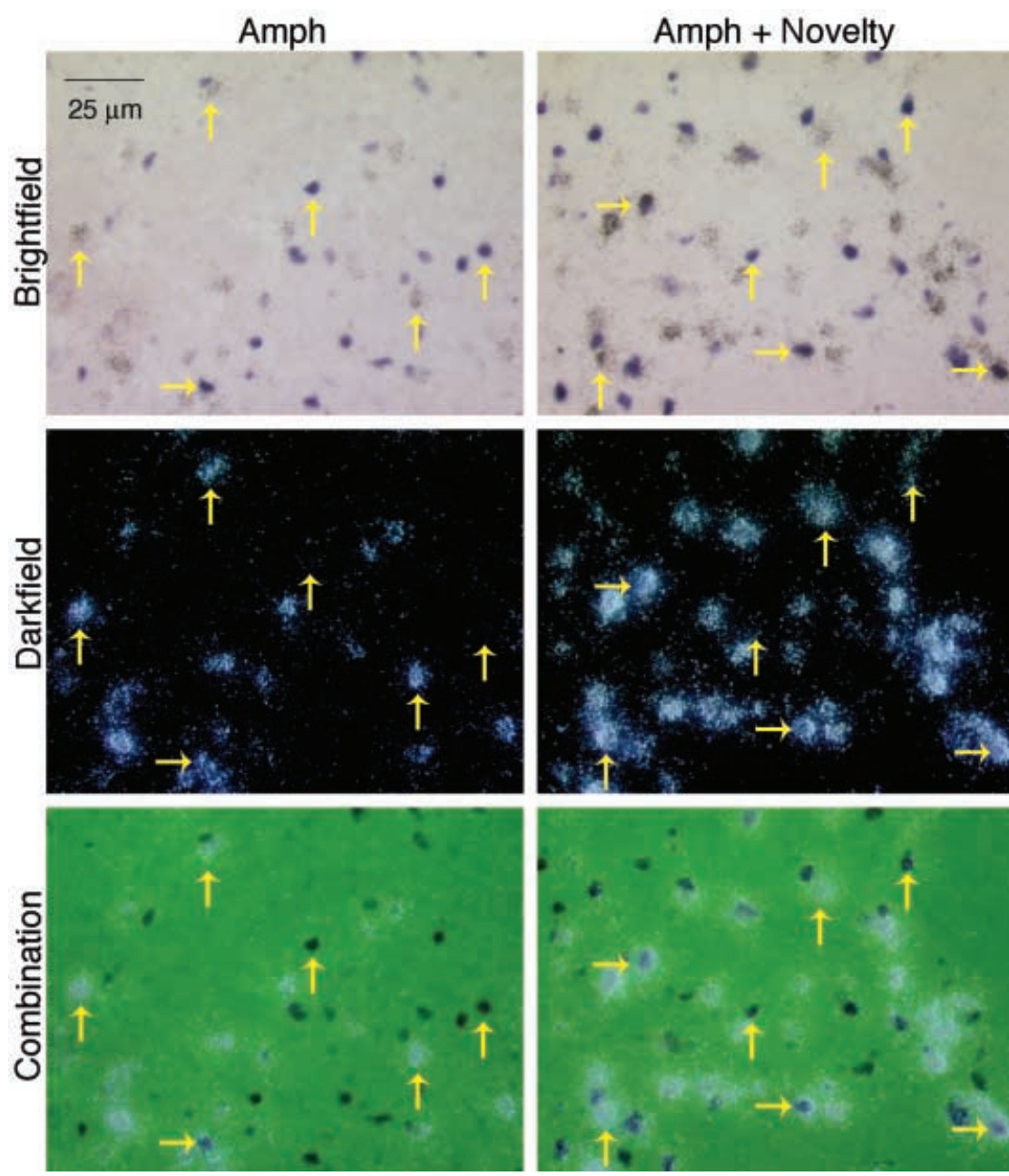

Fig. 2 Representative histological plates depicting sections from the $\mathrm{CPu}$ that are double-labeled for c-fos mRNA and preproenkephalin mRNA. The panels on the left are from animals given amphetamine at home and the panels on the right are from animals given amphetamine in the novel environment. (Top) Brightfield images in which Enk+ cells are indicated by purple precipitate. (Middle) Darkfield images in which c-fos+ cells are indicated by clusters of silver grains. (Bottom) Overlay of brightfield and darkfield images. Up arrows indicate single-labeled cells (c-fos+ or Enk+). Right arrows indicate double-labeled cells (c-fos/Enk+). (top) shows that by itself L-741,262 slightly increased the total number of c-fos + cells in animals given saline at home (i.e. basal levels of expression), although this effect reached statistical significance only at the highest dose used. Nevertheless, L-741,262 dose-dependently reduced the total number of c-fos + cells in animals given amphetamine, regardless of environmental condition. There was no effect of L-741,262 in animals given saline in the novel environment (top panels). The bottom panels show that the effectiveness of L-741,262 differed depending on cell type and treatment condition. The figure inset (bottom) shows that L-741,262 by itself dose-dependently increased basal levels of c-fos expression in both Dyn-SP+ and Enk + cells, although this effect reached statistical significance only in Enk + cells and only at the highest dose tested. In animals given amphetamine at home (panel E), L-741,262 dose-dependently reduced the number of c-fos/Dyn-SP+ cells. In animals given amphetamine in the novel environment (panel F), L-741,262 dosedependently reduced the number of c-fos/Enk+ cells, but had no significant effect on the number of c-fos/Dyn-SP+ cells. In animals given saline in the novel environment (panel D),
L-741,262 had no significant effect on c-fos expression in either type of cell.

\section{Effect of the NMDAR antagonists CPP, ifenprodil and MK-801 on c-fos mRNA expression in Dyn-SP+} and Enk+ cells

The effect of pre-treatment with the NMDAR antagonist CPP on c-fos expression is depicted in Fig. 6. The top panels show that CPP dose-dependently reduced the total number of c-fos + cells in animals given amphetamine at home or in the novel environment. The effect of CPP in animals given saline in the novel environment was not statistically significant. The bottom panels show that the effectiveness of CPP differed depending on cell type and treatment condition. In animals given amphetamine at home (panel E), CPP reduced the number of c-fos/Dyn-SP+ cells only at the highest dose tested. Similarly, in animals given amphetamine in the novel environment (panel F), CPP reduced the number of c-fos/Dyn-SP+ cells only at the highest dose tested. In contrast, both doses of CPP markedly reduced the number of $\mathrm{c}-f \circ s /$ Enk + cells in the 


\section{DA D1R Antagonism}

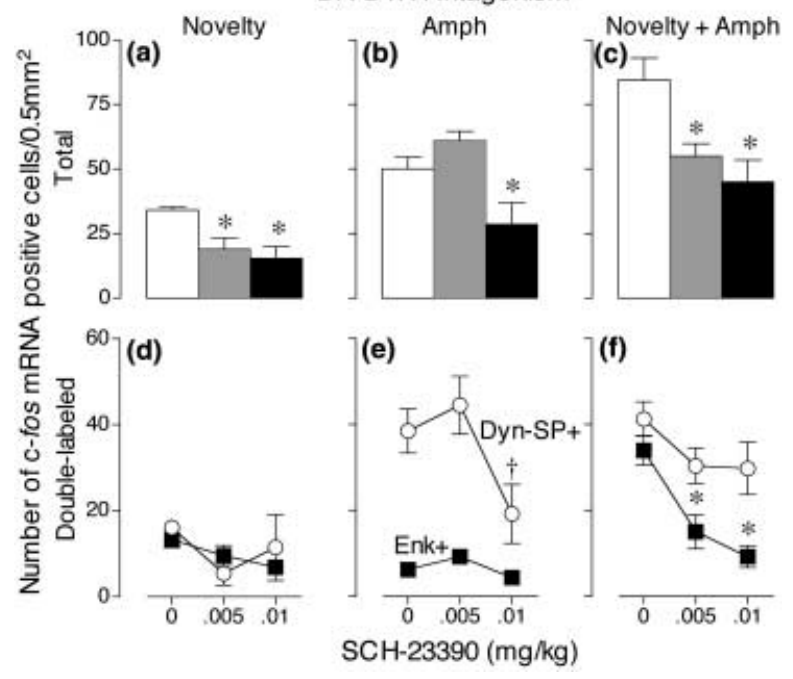

Fig. 3 Expression of c-fos mRNA in the dorso-caudal CPu after pretreatment with the D1R antagonist SCH-23390. Top panels $(a-c)$ depict the total number of $c-f o s+$ cells and bottom panels ( $d-f)$ depict the number of c-fos/Dyn-SP+ cells (white circles) or c-fos/Enk+ cells (black squares) as a function of treatment and environmental condition. SCH-23390 significantly decreased the total number of c-fos+ cells in all conditions (panel $a, F_{2,9}=14.14, p=0.002$; panel $b$, $F_{2,15}=7.86, p=0.005$; panel $c, F_{2,14}=7.11, p=0.01$ ). There was no significant effect of $\mathrm{SCH}-23390$ on the number of $c-f o s / D y n-S P+$ in the novelty stress or novel/amphetamine groups (panel d, $F_{2,9}=2.13$, $p=0.17$; panel f, $F_{2,14}=1.96, p=0.18$ ), but $\mathrm{SCH}-23390$ did have a significant effect on the home/amphetamine group (panel e, $\left.F_{2,14}=4.23, p=0.04\right)$. SCH-23390 decreased the number of c-fos/ Enk+ cells only when amphetamine was given in the novel environment (panel d, $F_{2,9}=2.81, p=0.11$; panel e, $F_{2,15}=2.93, p=0.08$; panel f, $\left.F_{2,13}=15.80, p=0.0003\right)$. *, differs from $0 \mathrm{mg} / \mathrm{kg}(p<0.05$, Dunnett's-test); $\dagger$, this paired comparison was not quite statistically significant $(p<0.1$, Dunnett's-test), although the overall ANOVA was significant (above).

novel condition. In animals given saline in the novel environment (panel D), CPP had no significant effect on c-fos expression in either type of cell.

In a second independent experiment, the effect of MK-801 was examined using the same experimental design. At the doses tested $(0.5$ and $1 \mathrm{mg} / \mathrm{kg})$ MK- 801 reduced c-fos expression to basal levels in all groups (data not shown).

Neither CPP nor MK-801 distinguishes between NMDARs that contain the main types of NR2 subunits in the striatum (i.e. NR2A and NR2B). However, NMDARs containing NR2B subunits have been associated with enhanced plasticity (Quinlan et al. 1999; Tang et al. 1999); and therefore, we also examined the effect of ifenprodil, a NR2B subunit-selective NMDAR antagonist. Figure 7 shows the effect of pre-treatment with ifenprodil on c-fos expression. The top panels show that ifenprodil reduced the total number of c-fos + cells in animals given amphetamine regardless of environmental condition. The effect of ifen-

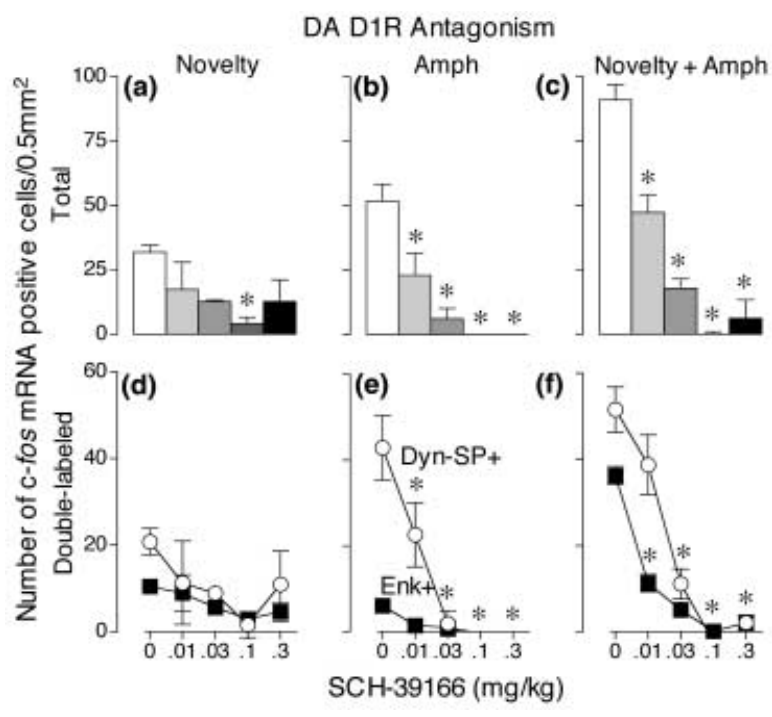

Fig. 4 Expression of c-fos mRNA in the dorso-caudal CPu after pretreatment with the D1R antagonist SCH-39166. Top panels $(a-c)$ depict the total number of $c-f o s+$ cells and bottom panels $(d-f)$ depict the number of $\mathrm{c}-\mathrm{fos} / \mathrm{Dyn}-\mathrm{SP}+$ cells (white circles) or c-fos/Enk+ cells (black squares) as a function of treatment and environmental condition. SCH-39166 significantly decreased the total number of c-fos+ cells in all conditions (panel a, $F_{4,13}=4.60, p=0.02$; panel $b$, $F_{4,25}=20.82, p<0.0001$; panel c, $\left.F_{4,25}=48.03, p<0.0001\right)$. SCH39166 significantly decreased the number of $c-f o s / D y n-S P+$ in the home/amphetamine group (panel e, $F_{4,25}=17.16, p<0.0001$ ), the novel/amphetamine group (panel f, $F_{4,25}=23.61, p<0.0001$ ) but not the novelty stress group (panel $\mathrm{d}, F_{4,13}=2.11, p=0.14$ ). Similarly, $\mathrm{SCH}-39166$ significantly decreased the number of c-fos/Enk+ cells in the novel/amphetamine group (panel f, $F_{4,21}=86.87, p<0.0001$ ) but not the novelty stress group (panel d, $F_{4,13}=2.42, p=0.10$ ). * , differs from $0 \mathrm{mg} / \mathrm{kg}$ ( $p<0.05$, Dunnett's-test).

prodil in animals given saline in the novel environment was not statistically significant. The bottom panels show that the effectiveness of ifenprodil differed depending on cell type and treatment condition. In animals given amphetamine at home (panel E), the highest dose of ifenprodil markedly decreased the number of c-fos/Dyn-SP+ cells. In animals given amphetamine in the novel environment (panel F), ifenprodil had no effect on the number of c-fos/Dyn-SP+ cells, but both doses significantly decreased the number of c-fos/Enk+ cells. In animals given saline in the novel environment (panel D), ifenprodil had no significant effect on c-fos expression in either type of cell.

\section{Discussion}

Regulation of c-fos expression in Dyn-SP+ cells evoked by amphetamine given at home

When given in the home cage, amphetamine evoked c-fos expression primarily in Dyn-SP+ cells (i.e. $87 \%$ of c-fos ${ }^{+}$ 


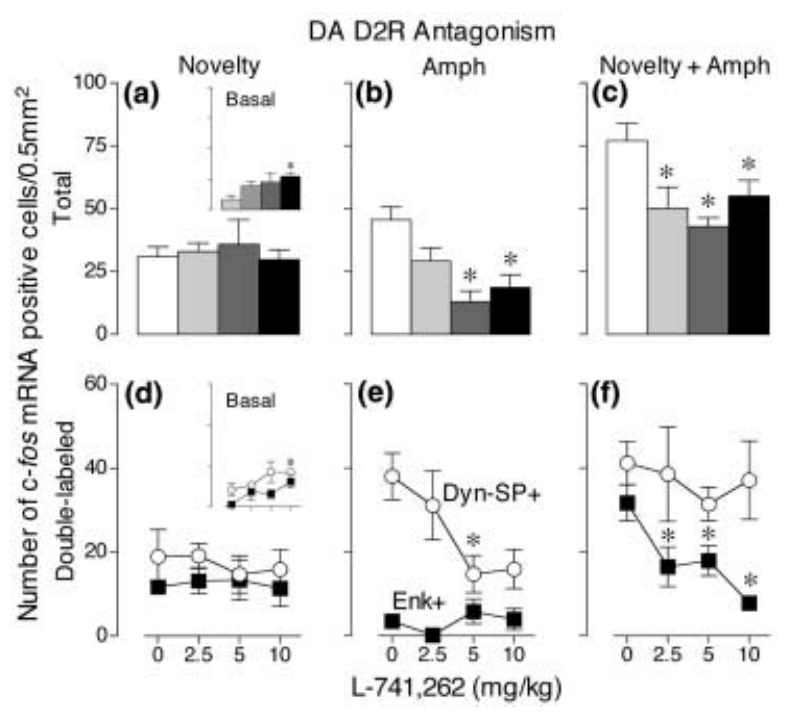

Fig. 5 Expression of c-fos mRNA in the dorso-caudal CPu after pretreatment with the D2R antagonist $L-741,262$. Top panels (a-c) depict the total number of $c-f o s+$ cells and bottom panels $(\mathrm{d}-\mathrm{f})$ depict the number of c-fos/Dyn-SP+ cells (white circles) or c-fos/Enk+ cells (black squares) as a function of treatment and environmental condition. L-741,262 significantly increased basal levels of c-fos expression (inset, $F_{3,13}=3.56, p=0.04$ ) but this effect was significant only in c-fos/Enk+ cells (inset, $F_{3,12}=4.25, p=0.03$ ). L-741,262 significantly decreased the total number of c-fos+ cells in the home/amphetamine group (panel $b, F_{3,20}=7.97, p=0.001$ ), the novel/amphetamine group (panel $c, F_{3,21}=6.21, p=0.004$ ) but not the novelty stress group (panel a, $F_{3,14}=0.22, p=0.88$ ). Interestingly, $\mathrm{L}-741,262$ significantly decreased the number of c-fos/Dyn-SP+ in the home/amphetamine group (panel e, $F_{3,18}=3.45, p=0.04$ ) but neither the novel/amphetamine group (panel f, $F_{3,18}=0.33, p=0.81$ ) nor the novelty stress group (panel $d, F_{3,12}=0.57, p=0.65$ ). However, L-741,262 significantly decreased the number of c-fos/Enk+ cells in the novel/amphetamine group (panel f, $F_{3,21}=7.14, p=0.002$ ) but not the novelty stress group (panel d, $F_{3,14}=0.10, p=0.96$ ). *, differs from $0 \mathrm{mg} / \mathrm{kg}$ ( $p<0.05$, Dunnett's-test).

cells were also Dyn-SP+). Under these conditions, all of the DAR and NMDAR antagonists tested dose-dependently decreased c-fos expression in these cells. This is consistent with the existing literature on the effects of DA (Graybiel et al. 1990; Berretta et al. 1992; Cenci et al. 1992; Ruskin and Marshall 1994; Drago et al. 1996; Moratalla et al. 1996; LaHoste et al. 2000) and glutamate receptor antagonists (Dragunow et al. 1991; Snyder-Keller 1991; Cenci and Bjorklund 1993; Wang et al. 1994; Vargo and Marshall 1995; Konradi et al. 1996) on psychostimulant-evoked c-fos expression. There is a general consensus, therefore, that when given at home psychostimulants induce c-fos in Dyn$\mathrm{SP}+$ cells via $\mathrm{D} 1 \mathrm{R}$ activation of the cAMP/PKA signaling cascade, and this is further regulated by D2Rs and NMDARs (Graybiel et al. 1990; Konradi et al. 1994; Ruskin and Marshall 1994; Cole et al. 1995; Konradi et al. 1996;

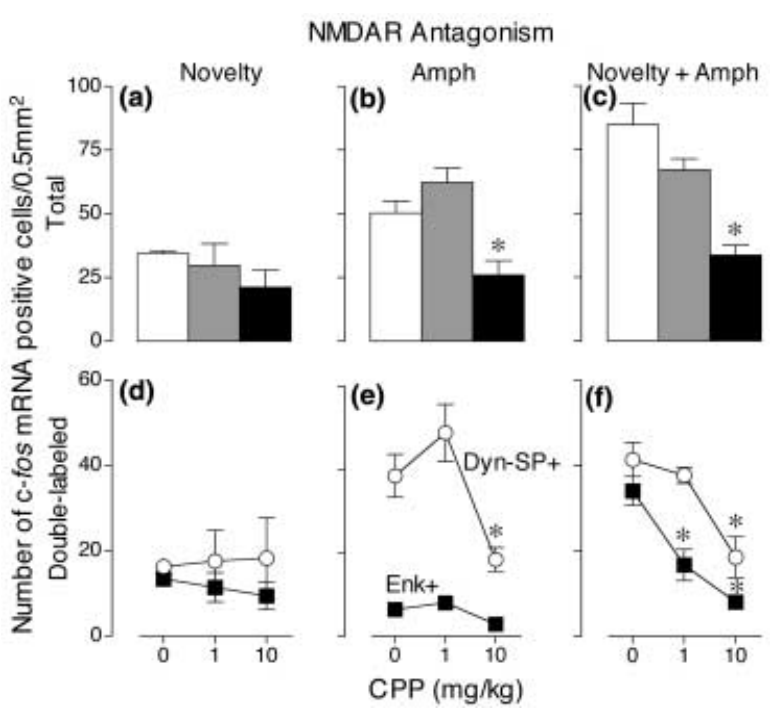

Fig. 6 Expression of c-fos mRNA in the dorso-caudal CPu after pretreatment with the NMDAR antagonist CPP. Top panels $(\mathrm{a}-\mathrm{C})$ depict the total number of $c-f o s+$ cells and bottom panels $(d-f)$ depict the number of c-fos/Dyn-SP+ cells (white circles) or c-fos/Enk+ cells (black squares) as a function of treatment and environmental condition. CPP significantly decreased the total number of c-fos+ cells in the home/amphetamine group (panel $\mathrm{b}, F_{2,15}=12.41, p=0.001$ ), the novel/amphetamine group (panel c, $F_{2,15}=19.15, p<0.0001$ ) but not the novelty stress group (panel a, $F_{2,9}=2.14, p=0.17$ ). Likewise, CPP significantly decreased the number of c-fos/Dyn-SP+ in the home/amphetamine group (panel e, $F_{2,15}=8.78, p=0.003$ ), the novel/amphetamine group (panel f, $F_{2,15}=10.73, p=0.001$ ) but not the novelty stress group (panel d, $F_{2,9}=0.04, p=0.99$ ). CPP also significantly decreased the number of c-fos/Enk+ cells in the novel/ amphetamine group (panel f, $F_{2,15}=19.92, p<0.0001$ ) but not the novelty stress group (panel $d, F_{2,9}=0.66, p=0.54$ ). *, differs from $0 \mathrm{mg} / \mathrm{kg}(p<0.05$, Dunnett's-test).

LaHoste et al. 2000; see McGinty and Wang 1998 for review).

Regulation of c-fos expression in Dyn-SP+ cells evoked by amphetamine given in a novel environment

When given in a novel environment, amphetamine-induced c-fos expression in both Dyn-SP+ and Enk+ cells (i.e. $61 \%$ of c-fos + cells were Dyn-SP+ and $35 \%$ of c-fos + cells were Enk + ). The mechanisms by which psychostimulants given in a novel environment induce IEGs in Dyn-SP+ cells have never been studied. We found that under this condition D1R antagonists and non-selective NMDAR antagonists decreased c-fos expression in Dyn-SP+ cells but there was no effect of D2R or NR2B-selective NMDAR antagonists. Thus, when amphetamine was given at home, all of the antagonists tested reduced c-fos expression in Dyn-SP+ cells, but when amphetamine was given in a novel environment, D2R and NR2B-selective NMDAR antagonists did not. 


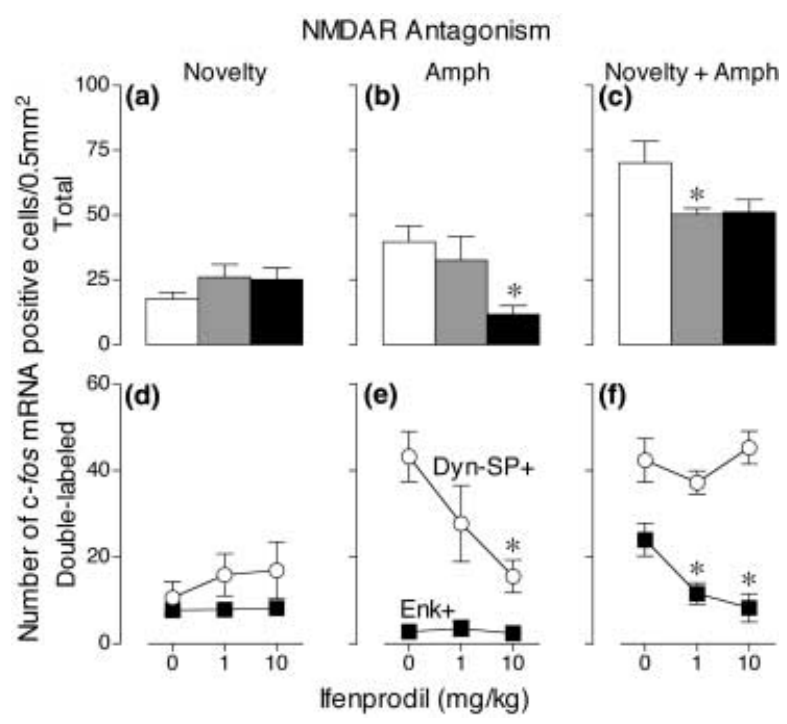

Fig. 7 Expression of c-fos mRNA in the dorso-caudal CPu after pretreatment with the NMDAR antagonist ifenprodil. Top panels $(a-c)$ depict the total number of $\mathrm{c}$-fos+ cells and bottom panels (d-f) depict the number of c-fos/Dyn-SP+ cells (white circles) or c-fos/Enk+ cells (black squares) as a function of treatment and environmental condition. Ifenprodil significantly decreased the total number of c-fos+ cells in the home/amphetamine group (panel $b, F_{2,17}=5.43, p=0.02$ ), the novel/amphetamine group (panel c, $F_{2,18}=3.86, p=0.04$ ) but not the novelty stress group (panel a, $F_{2,9}=1.09, p=0.38$ ). Interestingly, ifenprodil significantly decreased the number of c-fos/Dyn-SP+ in the home/amphetamine group (panel e, $F_{2,16}=4.82, p=0.02$ ) but not the novel/amphetamine group (panel f, $F_{2,18}=1.06, p=0.37$ ) nor the novelty stress group (panel $d, F_{2,9}=0.57, p=0.59$ ). Ifenprodil significantly decreased the number of c-fos/Enk+ in the novel/amphetamine group (panel $\mathrm{f}, F_{2,17}=6.53, p=0.008$ ) but not the novelty stress group (panel d, $F_{2,9}=0.06, p=0.95$ ). *, differs from $0 \mathrm{mg} / \mathrm{kg}$ $(p<0.05$, Dunnett's-test).

It is unclear what accounts for the different effects of DA D2R and NR2B-selective NMDAR antagonists on amphetamine-evoked c-fos expression, as a function of environmental condition. One possibility is that environmental novelty enhances amphetamine-stimulated DA release and therefore higher doses of these antagonists are required under this condition. However, environmental novelty did not significantly increase the total number of amphetamineevoked c-fos/Dyn-SP+ cells (present study), and microdialysis studies have shown that environmental novelty has no effect on amphetamine-evoked DA release in the $\mathrm{CPu}$ or nucleus accumbens (Badiani et al. 1997, 1998).

Psychostimulants are thought to induce IEG expression in Dyn-SP+ cells via D1R activation of the cAMP/PKA signaling cascade (Graybiel et al. 1990; Konradi et al. 1994; Cole et al. 1995); and therefore, exposure to environmental novelty may facilitate activation of this intracellular signaling cascade. Perhaps exposure to a novel environment enhances the binding affinity of DA for DARs or increases
DAR reserves on Dyn-SP+ cells, either through an increase in receptor density or through alterations in G-protein/ receptor coupling. These changes would decrease the amount of DA required to trigger D1R-mediated intracellular signaling cascades that induce IEG expression in Dyn-SP+ cells, and consequently higher doses of antagonists would be needed to block the effect. This is an unlikely explanation, however, given that there were no significant differences in the ability of the D1R antagonists to block amphetamineevoked c-fos expression in Dyn-SP+ cells under either condition and that doses of D2R or NR2B subunit-selective NMDAR antagonists that were capable of blocking c-fos expression in Dyn-SP+ cells when amphetamine was administered in the home cage had no effect on c-fos expression in Dyn-SP+ cells when amphetamine was administered in the novel environment.

This leaves the intriguing possibility that the mechanism(s) by which amphetamine induces c-fos expression in Dyn-SP+ cells differs as a function of the context in which it is administered. Perhaps environmental novelty recruits other neurotransmitter systems that interact with D1R-mediated intracellular signaling cascades. For example, mere exposure to a novel environment markedly activates the neocortex, presumably engaging corticostriatal glutamate afferents to the $\mathrm{CPu}$, and this effect is amplified when amphetamine is given in a novel environment (Badiani et al. 1998; Uslaner et al. 2001a). Although the activation of corticostriatal glutamate afferents induces c-fos primarily in Enk+ cells (Berretta et al. 1997; Parthasarathy and Graybiel 1997; Sgambato et al. 1997), direct intrastriatal infusions of glutamate agonists or cortical stimulation can also induce c-fos in a subpopulation of striatal interneurons that are positive for NADPH-diaphorase (Berretta et al. 1992, 1997). Interestingly, these interneurons do not contain D2Rs and contain low levels of NR2B subunit-containing NMDARs (Yung et al. 1995; Standaert et al. 1999). Moreover, psychostimulant administration at home does not evoke c-fos expression in NADPH-diaphorase+ interneurons (Berretta et al. 1992). Thus, it is conceivable that these interneurons are activated by glutamate following exposure to a novel environment and are capable of modulating amphetamineevoked c-fos expression in Dyn-SP+ cells, likely via neuronal nitric oxide synthase (nNOS) signaling mechanisms (Kawaguchi et al. 1995).

It is also possible that additional neurotransmitter systems interact with DA and glutamate to modulate amphetamine-induced c-fos expression in Dyn-SP+ cells, depending on the context in which amphetamine is given. For example, 5-HTR agonists induce c-fos expression primarily in Dyn-SP+ cells, an effect that is reversed by 5-HTR or D1R antagonists (Li and Rowland 1993; Gardier et al. 2000), suggesting 5-HT as a candidate. Another candidate is acetylcholine, as intrastriatal infusions of muscarinic receptor agonists and antagonists differentially 
regulate amphetamine-evoked neuropeptide expression in Dyn-SP+ cells (Wang and McGinty 1997).

Finally, another interesting possibility is that the ability of DA and glutamate to regulate c-fos expression in Dyn-SP+ cells is contingent on the activation state of Enk+ cells. In the novel condition, D2R and NR2B subunit-selective NMDAR antagonists are highly effective at blocking amphetamineinduced c-fos expression in Enk + cells. A consequence of this antagonism could be dis-inhibition of Dyn-SP+ cells, which would manifest itself as an apparent loss of an effect of these antagonists. In support of this, in vivo electrophysiology studies have found that D2R antagonism increases cortical stimulation-evoked excitatory post-synaptic potentials (EPSPs) in striatal neurons, which leads to a facilitation in D1R-mediated neuronal activity (West and Grace 2002).

\section{Regulation of c-fos expression in Enk+ cells evoked by amphetamine given in a novel environment}

Amphetamine-evoked c-fos expression in Enk + cells was extremely sensitive to all of the antagonists tested. Indeed, the lowest dose of every antagonist tested significantly reduced c-fos expression in Enk+ cells, but the same dose had no effect on c-fos expression in Dyn-SP+ cells. Furthermore, D2R and NR2B subunit-selective NMDAR antagonists dose-dependently reduced c-fos expression in Enk + cells, but had no effect on c-fos expression in Dyn-SP+ cells in the novel environment.

The receptors involved in the ability of psychostimulant drugs to induce IEGs in Enk+ cells have never been studied. However, stimulation of corticostriatal afferents induces c-fos preferentially in Enk+ cells, an effect that is blocked by NMDAR antagonists (Berretta et al. 1997; Parthasarathy and Graybiel 1997; Sgambato et al. 1997), and is thought to occur via activation of the extracellular signal-regulated kinase/mitogen-activated protein kinase (ERK1/2/MAPK) signaling pathway (Sgambato et al. 1998a,b; Gerfen et al. 2002). DA modulates the ability of glutamate to activate this pathway, because D1R antagonists block and D2R antagonists potentiate cortical stimulation-evoked c-fos expression in the striatum (Fu and Beckstead 1992; Liste et al. 1995; Berretta et al. 1997, 1999). Given that amphetamine administration in a novel environment is accompanied by strong activation of the neocortex, it is reasonable to hypothesize that under these conditions amphetamine induces c-fos expression in Enk + cells via NMDAR-mediated activation of intracellular signaling cascades. The effects of NMDAR antagonists reported here support this idea. It is less clear, however, why D1R and D2R receptor antagonists were also more effective in reducing c-fos expression in Enk+ cells than in Dyn-SP+ cells.

It is possible that the mechanism by which cortical stimulation induces c-fos expression in Enk+ cells is different than the mechanism by which amphetamine in a novel environment induces c-fos in Enk+ cells. For example, DA can potentiate the post-synaptic effects of glutamate, and the relative balance of DA and glutamate receptor signaling may determine which intracellular signaling cascades are engaged in what cells (Carlsson and Carlsson 1990; Lindefors and Ungerstedt 1990; Gerfen et al. 2002). Thus, when cortical activation is coupled with high levels of DA release (as would occur following amphetamine administration in a novel environment), perhaps NMDAR-mediated activation of IEG expression in Enk+ cells is facilitated, and this is highly susceptible to both DA and glutamate receptor antagonism. Further studies are needed to explore the manner in which DA and glutamate interact to modulate the mechanisms that underlie IEG expression in Enk+ cells under different conditions.

In the present study, antagonists were injected systemically and therefore it is possible that c-fos expression was decreased through actions at sites outside the $\mathrm{CPu}$. We know of no studies on the effects of direct intrastriatal infusions of these antagonists specifically on psychostimulant-induced IEG expression in neurologically intact animals. However, intrastriatal infusions of D1R antagonists decrease apomorphine-induced IEG expression in intact animals and intrastriatal infusions of D1R, D2R or NMDAR antagonists decrease IEG expression induced by direct $\mathrm{D} 1 \mathrm{R}-$ and $\mathrm{D} 1 \mathrm{R}+\mathrm{D} 2 \mathrm{R}$ agonists in dopamine denervated animals (Keefe and Gerfen 1995, 1996). NMDAR antagonists also decrease psychostimulant-induced IEG expression in dissociated striatal cell cultures (Konradi et al. 1996). Furthermore, it is unlikely that D1R antagonists acted in the cortex to block corticostriatal glutamate release because D1R antagonists do not alter amphetamine-induced Fos expression in the cerebral cortex (Graybiel et al. 1990) and it is unlikely that the NMDAR antagonists acted in the substantia nigra to block dopamine release because intranigral infusions of NMDAR antagonists potentiate, rather than decrease, D1R agonist-induced c-fos expression in unilateral 6-OHDAlesioned rats (Fenu et al. 1995; McPherson and Marshall 2000). In addition, c-fos mRNA expression in the region of anterior cingulate that projects to dorso-caudal $\mathrm{CPu}$ was analyzed in the present study and there were no major differences in cortical c-fos expression as a function of antagonist pre-treatment (except for a decrease in cortical c-fos expression seen in the highest dose of CPP in the novel environment, data not shown). We conclude, therefore, that the effects of antagonists reported here are likely due to their actions within the $\mathrm{CPu}$, but further studies will be necessary to test this hypothesis.

\section{Regulation of novelty stress-evoked c-fos expression}

Novelty stress also induced c-fos expression in both Dyn$\mathrm{SP}+$ and Enk + cells (i.e. $68 \%$ of c-fos + cells were Dyn-SP+ and $33 \%$ of $\mathrm{c}-f o s+$ cells were Enk + ). The total number of c-fos + cells was much less than that seen after amphetamine administration in a novel environment, but the proportion of 
c-fos/Dyn-SP+ and c-fos/Enk+ cells was similar. This suggests that amphetamine may simply amplify the actions of novelty stress. However, the effects of the antagonists do not support this otherwise straight-forward interpretation. Only D1R antagonists reduced novelty stress-induced c-fos expression in either cell population. The fact that D2R and NMDAR antagonists were relatively ineffective suggests that the ability of novelty stress to induce c-fos in either cell population may involve different mechanisms than is the case with amphetamine. Perhaps these differences also involve the relative balance of DA and glutamate signaling, or interactions with other neurotransmitters systems.

\section{Conclusion}

The most important message from the present study is that different mechanisms are likely involved in the ability of amphetamine or novelty stress to induce c-fos expression in different cell populations in the $\mathrm{CPu}$, depending on environmental context. Given that the ability of drugs of abuse to induce IEGs represents a critical step in the development of many forms of drug experience-dependent neuroplasticity related to addiction (Nestler et al. 1993; Hyman and Malenka 2001), it will be critical to delineate how the pharmacological effects of drugs interact with environmental factors to determine which neurotransmitters systems, receptors and intracellular signaling cascades are engaged to alter gene expression.

\section{Acknowledgements}

This research was supported by a NIDA grant to TER (R37 DA04294) and NIDA grants to HA and SJW (R01 DA13386 and R01 DA08920). TER was supported by a Senior Research Scientist Award (K05 DA00473) and SMF by an Individual NRSA (F31 DA14737), both from NIDA. We thank Yilin Li and Jason Uslaner for their assistance in conducting these experiments.

\section{References}

Badiani A., Camp D. M. and Robinson T. E. (1997) Enduring enhancement of amphetamine sensitization by drug-associated environmental stimuli. J. Pharmacol. Exp. Ther. 282, 787-794.

Badiani A., Oates M. M., Day H. E., Watson S. J., Akil H. and Robinson T. E. (1998) Amphetamine-induced behavior, dopamine release, and c-fos mRNA expression: modulation by environmental novelty. J. Neurosci. 18, 10579-10593.

Badiani A., Oates M. M., Day H. E., Watson S. J., Akil H. and Robinson T. E. (1999) Environmental modulation of amphetamine-induced c-fos expression in D1 versus D2 striatal neurons. Behav. Brain Res. 103, 203-209.

Berretta S., Robertson H. A. and Graybiel A. M. (1992) Dopamine and glutamate agonists stimulate neuron-specific expression of Fos-like protein in the striatum. J. Neurophysiol. 68, 767-777.

Berretta S., Robertson H. A. and Graybiel A. M. (1993) Neurochemically specialized projection neurons of the striatum respond differentially to psychomotor stimulants. Prog. Brain Res. 99, 201-205.
Berretta S., Parthasarathy H. B. and Graybiel A. M. (1997) Local release of GABAergic inhibition in the motor cortex induces immediateearly gene expression in indirect pathway neurons of the striatum. J. Neurosci. 17, 4752-4763.

Berretta S., Sachs Z. and Graybiel A. M. (1999) Cortically driven Fos induction in the striatum is amplified by local dopamine D2-class receptor blockade. Eur. J. Neurosci. 11, 4309-4319.

Carlsson M. and Carlsson A. (1990) Interactions between glutamatergic and monoaminergic systems within the basal ganglia - implications for schizophrenia and Parkinson's disease. Trends Neurosci. 13, 272-276.

Cenci M. A. and Bjorklund A. (1993) Transection of corticostriatal afferents reduces amphetamine- and apomorphine-induced striatal Fos expression and turning behaviour in unilaterally 6-hydroxydopamine-lesioned rats. Eur. J. Neurosci. 5, 1062-1070.

Cenci M. A., Kalen P., Mandel R. J., Wictorin K. and Bjorklund A. (1992) Dopaminergic transplants normalize amphetamine- and apomorphine-induced Fos expression in the 6-hydroxydopaminelesioned striatum. Neuroscience 46, 943-957.

Cole R. L., Konradi C., Douglass J. and Hyman S. E. (1995) Neuronal adaptation to amphetamine and dopamine: molecular mechanisms of prodynorphin gene regulation in rat striatum. Neuron 14, 813-823.

Curran E. J. and Watson S. J. Jr (1995) Dopamine receptor mRNA expression patterns by opioid peptide cells in the nucleus accumbens of the rat: a double in situ hybridization study. J. Comp. Neurol. 361, 57-76.

Drago J., Gerfen C. R., Westphal H. and Steiner H. (1996) D1 dopamine receptor-deficient mouse: cocaine-induced regulation of immediate-early gene and substance P expression in the striatum. Neuroscience 74, 813-823.

Dragunow M., Logan B. and Laverty R. (1991) 3,4-Methylenedioxymethamphetamine induces Fos-like proteins in rat basal ganglia: reversal with MK 801. Eur. J. Pharmacol. 206, 255-258.

Duffy R. A., Hunt M. A., Wamsley J. K. and McQuade R. D. (2000) In vivo autoradiography of $[3 \mathrm{H}] \mathrm{SCH} 39166$ in rat brain: selective displacement by D1/D5 antagonists. J. Chem. Neuroanat. 19, 41-46.

Falk J. L. and Feingold D. A. (1987) Environmental and cultural factors in the behavioral actions of drugs, in Meltzer, H. Y., ed. Psychopharmacology: The Third Generation of Progress, pp. 1503-1510. Raven Press, New York.

Fenu S., Carta A. and Morelli M. (1995) Intranigral injections of glutamate antagonists modulate dopamine D1-mediated turning behavior and striatal c-fos expression. J. Neural Transm. Suppl. 45, $75-81$.

Fu L. and Beckstead R. M. (1992) Cortical stimulation induces fos expression in striatal neurons. Neuroscience 46, 329-334.

Gardier A. M., Moratalla R., Cuellar B., Sacerdote M., Guibert B., Lebrec H. and Graybiel A. M. (2000) Interaction between the serotoninergic and dopaminergic systems in d-fenfluramineinduced activation of c-fos and jun B genes in rat striatal neurons. J. Neurochem. 74, 1363-1373.

Gerfen C. R., Miyachi S., Paletzki R. and Brown P. (2002) D1 dopamine receptor supersensitivity in the dopamine-depleted striatum results from a switch in the regulation of ERK1/2/MAP kinase. $J$. Neurosci. 22, 5042-5054.

Graybiel A. M., Moratalla R. and Robertson H. A. (1990) Amphetamine and cocaine induce drug-specific activation of the c-fos gene in striosome-matrix compartments and limbic subdivisions of the striatum. Proc. Natl Acad. Sci. USA 87, 6912-6916.

Harlan R. E. and Garcia M. M. (1998) Drugs of abuse and immediateearly genes in the forebrain. Mol. Neurobiol. 16, 221-267.

Hyman S. E. and Malenka R. C. (2001) Addiction and the brain: the neurobiology of compulsion and its persistence. Nat. Rev. Neurosci. 2, 695-703. 
Jaber M., Cador M., Dumartin B., Normand E., Stinus L. and Bloch B. (1995) Acute and chronic amphetamine treatments differently regulate neuropeptide messenger RNA levels and Fos immunoreactivity in rat striatal neurons. Neuroscience 65, 1041-1050.

Johansson B., Lindstrom K. and Fredholm B. B. (1994) Differences in the regional and cellular localization of $\mathrm{c}-\mathrm{fos}$ messenger RNA induced by amphetamine, cocaine and caffeine in the rat. Neuroscience 59, 837-849.

Kawaguchi Y., Wilson C. J., Augood S. J. and Emson P. C. (1995) Striatal interneurones: chemical, physiological and morphological characterization. Trends Neurosci. 18, 527-535.

Keefe K. A. and Gerfen C. R. (1995) D1-D2 dopamine receptor synergy in striatum: effects of intrastriatal infusions of dopamine agonists and antagonists on immediate early gene expression. Neuroscience 66, 903-913.

Keefe K. A. and Gerfen C. R. (1996) D1 dopamine receptor-mediated induction of zif268 and c-fos in the dopamine-depleted striatum: differential regulation and independence from NMDA receptors. J. Comp. Neurol. 367, 165-176.

Konradi C., Cole R. L., Heckers S. and Hyman S. E. (1994) Amphetamine regulates gene expression in rat striatum via transcription factor CREB. J. Neurosci. 14, 5623-5634.

Konradi C., Leveque J. C. and Hyman S. E. (1996) Amphetamine and dopamine-induced immediate early gene expression in striatal neurons depends on postsynaptic NMDA receptors and calcium. J. Neurosci. 16, 4231-4239.

LaHoste G. J., Henry B. L. and Marshall J. F. (2000) Dopamine D1 receptors synergize with $\mathrm{D} 2$, but not $\mathrm{D} 3$ or $\mathrm{D} 4$, receptors in the striatum without the involvement of action potentials. J. Neurosci. 20, 6666-6671.

Li B. H. and Rowland N. E. (1993) Dexfenfluramine induces Fos-like immunoreactivity in discrete brain regions in rats. Brain Res. Bull. 31, 43-48.

Lindefors N. and Ungerstedt U. (1990) Bilateral regulation of glutamate tissue and extracellular levels in caudate-putamen by midbrain dopamine neurons. Neurosci. Lett. 115, 248-252.

Liste I., Rozas G., Guerra M. J. and Labandeira-Garcia J. L. (1995) Cortical stimulation induces Fos expression in striatal neurons via NMDA glutamate and dopamine receptors. Brain Res. 700, 1-12.

McGinty J. F. and Wang J. Q. (1998) Drugs of abuse and striatal gene expression. Adv. Pharmacol. 42, 1017-1019.

McPherson R. J. and Marshall J. F. (2000) Substantia nigra glutamate antagonists produce contralateral turning and basal ganglia Fos expression: interactions with D1 and D2 dopamine receptor agonists. Synapse 36, 194-204.

Moratalla R., Xu M., Tonegawa S. and Graybiel A. M. (1996) Cellular responses to psychomotor stimulant and neuroleptic drugs are abnormal in mice lacking the D1 dopamine receptor. Proc. Natl Acad. Sci. USA 93, 14928-14933.

Nestler E. J., Hope B. T. and Widnell K. L. (1993) Drug addiction: a model for the molecular basis of neural plasticity. Neuron 11, 995-1006.

Parthasarathy H. B. and Graybiel A. M. (1997) Cortically driven immediate-early gene expression reflects modular influence of sensorimotor cortex on identified striatal neurons in the squirrel monkey. J. Neurosci. 17, 2477-2491.

Paxinos G. and Watson C. (1998) The Rat Brain in Stereotaxic Coordinates, 4th edn. Academic Press, San Diego.

Quinlan E. M., Philpot B. D., Huganir R. L. and Bear M. F. (1999) Rapid, experience-dependent expression of synaptic NMDA receptors in visual cortex in vivo. Nat. Neurosci. 2, 352-357.

Robinson T. E., Browman K. E., Crombag H. S. and Badiani A. (1998) Modulation of the induction or expression of psychostimulant sensitization by the circumstances surrounding drug administration. Neurosci. Biobehav. Rev. 22, 347-354.
Ruskin D. N. and Marshall J. F. (1994) Amphetamine- and cocaineinduced fos in the rat striatum depends on D2 dopamine receptor activation. Synapse 18, 233-240.

Sgambato V., Abo V., Rogard M., Besson M. J. and Deniau J. M. (1997) Effect of electrical stimulation of the cerebral cortex on the expression of the Fos protein in the basal ganglia. Neuroscience 81, 93-112.

Sgambato V., Pages C., Rogard M., Besson M. J. and Caboche J. (1998a) Extracellular signal-regulated kinase (ERK) controls immediate early gene induction on corticostriatal stimulation. J. Neurosci. 18, 8814-8825.

Sgambato V., Vanhoutte P., Pages C., Rogard M., Hipskind R., Besson M. J. and Caboche J. (1998b) In vivo expression and regulation of Elk-1, a target of the extracellular-regulated kinase signaling pathway, in the adult rat brain. J. Neurosci. 18, 214-226.

Snyder-Keller A. M. (1991) Striatal c-fos induction by drugs and stress in neonatally dopamine-depleted rats given nigral transplants: importance of NMDA activation and relevance to sensitization phenomena. Exp. Neurol. 113, 155-165.

Standaert D. G., Friberg I. K., Landwehrmeyer G. B., Young A. B. and Penney J. B. Jr (1999) Expression of NMDA glutamate receptor subunit mRNAs in neurochemically identified projection and interneurons in the striatum of the rat. Brain Res. Mol. Brain Res. 64, 11-23.

Tang Y. P., Shimizu E., Dube G. R., Rampon C., Kerchner G. A., Zhuo M., Liu G. and Tsien J. Z. (1999) Genetic enhancement of learning and memory in mice. Nature 401, 63-69.

Uslaner J., Badiani A., Day H. E., Watson S. J., Akil H. and Robinson T. E. (2001a) Environmental context modulates the ability of cocaine and amphetamine to induce c-fos mRNA expression in the neocortex, caudate nucleus, and nucleus accumbens. Brain Res. 920, $106-116$.

Uslaner J., Badiani A., Norton C. S., Day H. E., Watson S. J., Akil H. and Robinson T. E. (2001b) Amphetamine and cocaine induce different patterns of c-fos mRNA expression in the striatum and subthalamic nucleus depending on environmental context. Eur. J. Neurosci. 13, 1977-1983.

Uslaner J. M., Norton C. S., Watson S. J., Akil H. and Robinson T. E. (2003) Amphetamine-induced c-fos mRNA expression in the caudate-putamen and subthalamic nucleus: interactions between dose, environment, and neuronal phenotype. J. Neurochem. 85, $105-114$.

Vargo J. M. and Marshall J. F. (1995) Time-dependent changes in dopamine agonist-induced striatal Fos immunoreactivity are related to sensory neglect and its recovery after unilateral prefrontal cortex injury. Synapse 20, 305-315.

Wang J. Q. and McGinty J. F. (1997) Intrastriatal injection of a muscarinic receptor agonist and antagonist regulates striatal neuropeptide mRNA expression in normal and amphetamine-treated rats. Brain Res. 748, 62-70.

Wang J. Q., Daunais J. B. and McGinty J. F. (1994) NMDA receptors mediate amphetamine-induced upregulation of zif/268 and preprodynorphin mRNA expression in rat striatum. Synapse 18, 343-353.

West A. R. and Grace A. A. (2002) Opposite influences of endogenous dopamine D1 and D2 receptor activation on activity states and electrophysiological properties of striatal neurons: studies combining in vivo intracellular recordings and reverse microdialysis. J. Neurosci. 22, 294-304.

Young S. T., Porrino L. J. and Iadarola M. J. (1991) Cocaine induces striatal c-fos-immunoreactive proteins via dopaminergic D1 receptors. Proc. Natl Acad. Sci. USA 88, 1291-1295.

Yung K. K., Bolam J. P., Smith A. D., Hersch S. M., Ciliax B. J. and Levey A. I. (1995) Immunocytochemical localization of D1 and D2 dopamine receptors in the basal ganglia of the rat: light and electron microscopy. Neuroscience 65, 709-730. 